UDC 336.764.2

JEL Classification: G10, G13, G14

http://doi.org/10.21272/mmi.2019.2-12

Mallika Mathew,

Ph.D., Jagannath International Management School, India

M. M. Sulphey,

Ph.D., Professor, Prince Sattam Bin Abdulaziz University, Saudi Arabia

\title{
FINANCIAL INNOVATION MANAGEMENT OF VOLATILITY SPILLOVERS AT INDIAN GOLD FUTURES MARKET
}

\begin{abstract}
Volatility Spillover refers to the interaction between volatilities of different financial markets and volatilities can transfer between markets. It is generally understood that the volatility process will show the extent to which new information is assimilated by the market. The paper studies financial innovation management of the Volatility Spillover between the Indian Gold Futures and Spot Gold Commodity Market. This study has used the daily price of futures and spot market of Multi Commodity Exchange, Mumbai for a period of seven years from 1st October 2009 to 30th September 2016. The study employs Bivariate Exponential Generalized Autoregressive Conditional Heteroscedasticity $(E G A R C H)$ model to investigate innovative management of the volatility spillover dynamics. The Bivariate EGARCH Model result reveals that the GARCH effects are statistically significant, signifying that the degree of volatility persistence exists in the case of both Gold futures and spot market returns. This result indicates that there is a tendency for volatility to continue for long periods in both the markets, once a shock has occurred. The leverage effect parameters are positive and statistically significant for both futures and spot market return, indicating the existence of leverage effect. This indicates that positive shocks have a greater impact on this market than the negative shocks. The spillover coefficients are statistically significant for both futures and spot market return, indicating significant bi-directional spillovers exist across the futures and spot markets of Gold. The result indicates that the investor can use the information of one market to predict the behaviour of the other market. All the available information is reflected in the current price as the market assimilates immediately new information and as a consequence, there are no arbitrage opportunities. In contrast to the widely accepted hypothesis of the futures market, that due to its cost and hedging advantages, the futures market leads the spot market, the Indian Gold Futures market, during the period of study, fails to provide early information to spot market.
\end{abstract}

Keywords: EGARCH, gold futures, spillover, spot market returns, volatility.

Introduction. The basic characteristic of an efficient market is that the spot and futures market assimilate the fresh information available in the market at the same time. Market factors like constraints of short sale, cost of transaction, liquidity and other constraints results in a lead lag relationship between the cash and the futures market. Volatility Spillover refers to the interaction between volatilities of different financial markets and volatilities can transfer between markets. It is generally understood that the volatility process will show the extent to which new information is assimilated by market. Volatility spillovers are important as the arrival of new information is shown by changes in volatility (Cheung and $\mathrm{Ng}, 1996)$. The presence of volatility spillover indicates that one large shock surges the volatilities of not only its own market, but also in other markets as well (Hong, 2001). If volatility spillovers exist from one market to the other, then market agents who need to cover their risk exposure may use the market, which is transmitting volatility. As an example, we can say that the immediate impact and lagged effect of shocks between spot and derivatives price will facilitate decision-making regarding hedging and budget (Wahab and Lashgari, 1993). In short, an enhanced understanding of the dynamic relationship between spot and futures prices and its relation to basis helps to hedging in a more efficient way. Furthermore, information transmission can be measured by studying the volatility spillovers (Chan et al., 1991).

Literature Review. Volatility Spillover is an area of research where substantial attention has been given (Mallika and Sulphey, 2018), and volumes of literature has been accumulated. Lin and Tamvakis (2001) examined the spillover effects of energy futures on New York Mercantile Exchange (NYMEX) and

Cite as: Mathew, M., \& Sulphey, M. M. (2019). Financial Innovation Management of Volatility Spillovers at Indian Gold Futures Market. Marketing and Management of Innovations, 2, 131-140. http://doi.org/10.21272/mmi.2019.2-12 
the International Petroleum Exchange (IPE) in both non-overlapping and simultaneous trading hours. The results indicated that there is spillovers in mean returns found in the IPE morning section between the NYMEX and IPE energy futures markets. NYMEX effectively integrates past information; in addition to bidirectional transmission of variance spillovers. Furthermore, it was found that during simultaneous trading in both the markets, substantial spillover effects are present; in spite of the fact that the closing price of the proceeding day on NYMEX, noticeably affects IPE morning prices.

Yang et al. (2003) explored the volatility spillovers that take place in three main regions related to wheat production and exporting regions, namely, U.S., Canada, and the European Union (EU) for the period 1996-2002. The researchers studied the volatility spillover by employing the multivariate GARCH model and the results indicated that the volatility transmission occurs from Canada and the EU to the US and not vice versa. Moreover, there is volatility transmission from the EU to Canada and not vice versa. Feng et al. (2003) undertook a study in Malaysia based on analyzing the mechanism related to intertemporal information transmission that takes place between the palm oil futures market and the physical cash market. For carrying out the analysis, standard GARCH model estimation, Vector Error Correction Model, Granger Causality test and Super exogeneity test were used. The results indicated that there exists bidirectional volatility spillover amongst the two markets and cannot identify the price leader.

In a study conducted in Japan by Xiaoging and Fung (2005), the bivariate asymmetric GARCH model was used for investigating the flow of market information for gold, platinum, and silver futures contracts traded in both markets of the US and Japan. It was seen that there exist strong pricing transmissions across the two markets for these metal contracts. However, in case of returns, the direction of information flow is from the US market to Japanese market. The analysis indicated that strong volatility spillover feedback effects is existent between the two markets whose impact is equivalent and comparable.

Azizan et al. (2007) employed bivariate Auto Regressive Moving Average ARMA (p,q) EGARCH $(p, q)$ model's specifications for investigating the return and volatility spillovers between the futures market and spot market of Malaysian crude palm oil. The researcher used the daily price data of crude pam oil futures and spot markets between January 1990 and December 31, 2003. The results demonstrated that for both returns and volatility bidirectional information transmission takes place between the two markets. Using a dynamic conditional correlation GARCH model, Lien and Yang (2009) explored the short run return and volatility spillovers among the three major international copper futures exchanges: London Metal Exchange (LME), New York Mercantile Exchange (NYMEX), and Shanghai Futures Exchange (SHFE). The results indicated that there is strong return and volatility spillovers between LME and NYMEX. Furthermore, the results demonstrated significant bidirectional return spillover between LME and SHFE and unidirectional volatility spillover form the LME to SHFE.

Wu et al. (2011) used a volatility spillover model to study the spillover effects from crude oil prices to corn prices. The analysis showed that there are significant spillovers from crude oil prices to both corn cash and futures prices. On the basis of this strong volatility link, in order to manage corn price risk by using oil futures, implementation of a new corn-hedging strategy was proposed. Kaltalioglu and Soytas (2011) used agricultural raw material spot prices (ARMI), food spot prices (FPI), and oil spot prices (OPI) from 1980 to 2008 for studying the volatility spillover among oil, food consumption item, and agricultural raw material. The analysis showed that there exists no volatility spillover from oil markets to food and from oil markets to agricultural raw material market but there exists a bidirectional spillover between agricultural raw materials and oil markets.

Using VAR-GARCH model, Mensi et al. (2013) examined the volatility spillover between the S\&P 500 and commodity price indices for energy, food, gold and beverages for the period between 2000 and 2011. The results indicated that volatility spillover exists between the S\&P 500 and commodity markets. 
Furthermore, the oil and gold markets are highly influenced by the volatility of the S\&P 500. TrujilloBarrera et al. (2012) examined the volatility spillovers among the crude oil futures market, ethanol and corn futures markets from 2006 to 2011. The results indicated that there is strong volatility spillovers from crude oil to corn and ethanol markets as well as from the corn to ethanol market, but the opposite is not true.

Nazlioglu et al. (2013) examined the volatility spillover between oil and agricultural commoditieswheat, corn, soyabean, and sugar - for both pre (1986-2005) and post food price crisis (2006-2011) period. It is only post crisis that oil market risk is transmitted to corn, wheat, and soya bean markets. Volatility spillover was seen from wheat to oil market during both the periods, but sugar market is not affected by oil market risks. Ewing and Malik (2013) incorporated the structural breaks and then studied the volatility spillovers between the gold and oil futures by using univariate and bivariate $\mathrm{GARCH}$ models. After taking structural breaks into account, it was observed that there exists strong and direct volatility spillover between gold and oil returns.

Sehgal et al. (2013) used the GARCH-BEKK model for examining the volatility spillovers between the spot and futures markets in addition to the futures prices of three strategically linked oil markets: New York Mercantile Exchange (NYMEX), Inter-Continental Exchange (ICE), and Multi Commodity Exchange (MCX). It was confirmed that there was bilateral volatility spillovers between ICE futures and spot market. The innovations in the spot market had positive effect on the current futures price volatility, whereas the effect was negative from futures to spot market. There is unilateral volatility spillover from futures to spot market for MCX, and the effect was negative. In the case of NYMEX, there are no shortterm volatility spillovers; rather there is a long-term volatility spillover from futures to spot.

Using trivariate volatility spillover model, Sy et al. (2015) investigated about the volatility spillovers that take place from the futures market of soyabean oil (SO) to the spot and futures markets of crude palm oil (CPO). The results suggested that between $\mathrm{SO}$ futures and $\mathrm{CPO}$ futures markets there exists long run equilibrium relationship, but relationship does not exist between $\mathrm{SO}$ futures and CPO spot and between $\mathrm{CPO}$ futures and $\mathrm{CPO}$ spot prices. The volatility spillover takes place from $\mathrm{SO}$ futures prices to $\mathrm{CPO}$ spot and futures prices. Furthermore, the markets react more to bad news rather than good news. Thenmozhi and Priya (2008) used an univariate EC-EGARCH model for investigating the volatility spillover process between commodity futures and spot market for gold, silver, and crude oil in MCX, NYMEX, and TOCOM. The analysis indicated that bidirectional volatility spillover is existent for all the commodities in all the exchanges except for crude oil in MCX. Furthermore, it showed that asymmetric effect between futures and spot market exists for all the commodities in the exchanges except for gold market in MCX.

Using futures and their corresponding spot indices of 4 commodities in Multi-Commodity Exchange, Mahalik et al. (2009) studied the price discovery function and volatility spillovers in the Indian Cash and Futures Commodity market. VECM was used for examining the price discovery, and the bivariate EGARCH was used for studying volatility. The study revealed that in the agricultural, energy and commodity index, the discovery of price takes place in the futures market, but in the metal market, there is no co-integrating relationship between spot and futures market. Furthermore, it was seen that volatility spillover takes place from future to spot market for all the markets under study except the agricultural market, where the volatility spillover is from spot to future market.

Shihabudheen and Padhi $(2010)$ employed bivariate EGARCH $(1,1)$ model for examining the volatility spillover of six Indian commodities, namely, gold, silver, crude oil, castor seed, jeera and sugar. The results indicated that the volatility spillover takes place from futures to spot prices for all the commodities except sugar, where the volatility spillover exists from spot to futures. Srinivasan and Ibrahim (2012) used Bivariate ECM-EGARCH model for studying the process of discovery of prices and volatility spillovers in futures and spot markets of Gold in National Commodity Derivatives Exchange. 
The research observed that a leading role is taken by the Gold spot market and aided in discovery of Gold price. In addition to this, it was seen that the volatility spillovers was more from the spot to futures market than vice versa, which means that the flow of information is stronger from spots to futures market. Furthermore, it is observed in the study that there is no maturity and efficiency in the gold futures market with dissemination of information.

Srinivasan (2012) analysed the volatility spillovers among the four futures and spot indices, namely, MCXAGRI, MCXENERGY, MCXMETAL, and MCXCOMDEX of Multi Commodity Exchange of India by using bivariate EGARCH model. The results indicated that though there is persistence of bidirectional volatility spillover, for all MCX commodity markets the volatility spillovers takes place from the spot to futures market. Sehgal et al. (2013) examined twelve actively traded commodities from agricultural, metal and energy, and four futures indices and their spot prices for studying the price discovery and volatility spillover relationships. The research demonstrated that discovery of price takes place in the futures market for Chan, guarseed, Soyabean, Zinc, Lead, Copper, and Natural Gas as well as in Comdex, MCX Metal, and MCX energy indices. Volatility spillover from spot to futures market was confirmed in three commodities - Soyabean, Zinc and Natural Gas.

Mantu et al. (2014) applied bivariate EGARCH model for examining the volatility spillovers in Indian spot-futures commodity markets by using agriculture price index (LAGRI), energy price index (LENERGY), aggregate commodity index (LCOMDEX) and metal price index (LMETAL) of MultiCommodity Exchange. It was observed that no co-integrating relationship is present between metal futures price index and metal spots price index. The analysis carried out by using bivariate EGARCH showed that for LENERGY and LCOMDEX index the volatility spillover takes place from futures to the spot market, whereas agriculture spot price index acts as a source of volatility towards the agriculture futures price index.

Gupta and Varma (2015) examined the volatility spillovers between the futures and spot markets of rubber in India by using GARCH. It was observed that there is volatility persistence in both the markets. Furthermore, the Granger Causality test proved that there is bidirectional volatility spillover in the two markets, thereby, implying that spot price is both cause and consequence of futures trading activity in rubber. Volatility Spillovers have been analysed between stock futures and spot market (Chin et al., 1991; Kawaller et al., 1990; Thenmozhi and Thomas, 2007; Karmakar, 2009; Pati and Rajib, 2011; Yang et al., 2012); between commodity spot and futures (Srinivasan and Ibrahim, 2012; Sehgal, Rajput and Florent-Deisting, 2013); between oil markets globally (Sehgal et al., 2013) and between international stock markets (Booth et al.,1997). There are also many studies about volatility spillovers between spot and future exchange rates of currencies (Wang and Wang, 2001; Hong, 2001).

In various studies like those conducted by Wang and Wang (2001), Srinivasan and Ibrahim (2012) and Sehgal et al. (2013), etc., unidirectional volatility spillovers have been found, whereas researches conducted by Chin et al. (1991), Patia and Rajib (2011), Bhar (2001), Kanas (1998), Sehgal et al. (2013) and Karmakar (2009), etc. have found bi-directional volatility spillovers. Thus, there is substantial evidence of both unidirectional and bi-directional volatility spillovers between markets. GARCH models have been used to examine volatility spillovers between markets in all these researches. Engle, Takatoshi and Lin (1990) were the first to introduce the theory of volatility spillovers based on GARCH models. They called the volatility spillovers as «meteor showers».

Methodology and research methods. Nature and Data Sources: The study on financial innovation management of volatility spillovers for Gold Futures uses diurnal closing price of Futures contract and spot market of gold having a trading unit of 100 grams. The study is conducted for seven years from 1 st October 2009. The data regarding Gold Futures contract and Spot Gold have been taken from the official website of Multi Commodity Exchange (MCX). Throughout this study, spot and futures market 
returns are expressed as continuously compounded or log returns (hereafter returns) at time $t$, Rt, is calculated as follows:

$$
R t=\log (P t / P t-1)=\log P t-\log P t-1
$$

where Pt and Pt-1 are the daily closing prices of the gold futures contract and its corresponding underlying spot market at days, $t$ and $t-1$, respectively.

The study has been restricted to the prices of the near month contract, as it is seen that maximum liquidity is around the near month contract. A combined price series is formed by roll over process for nearby month futures for all contract's months under study. That is, the price is taken from the next maturing contract, when the near contract is approaching maturity. The shift to the next month contract is done one day before the expiry of the nearby contract.

Volatility Spillover: The study employs Exponential Generalized Autoregressive Conditional Heteroscedasticity (EGARCH) model to investigate innovative management of the volatility spillover dynamics. The basic GARCH is symmetric and does not record completely the asymmetry effect that is integral to most stock markets return data also known as the «leverage effect». As far as analysis of financial time series is concerned, the asymmetry effect shows the specific nature of times series on asset prices that «bad news» tend to increase the volatility rather than «good news» (Black, 1976; Nelson, 1991). The Exponential GARCH (EGARCH) model proposed by Nelson (1991) is particularly developed to document the asymmetry shock to the conditional variance. The Exponential GARCH model specifies conditional variance in logarithmic form, which means that there is no need to impose estimation constraints in order to avoid negative variance Nelson (1991). The mean and variance equation for this model is given by:

$$
\begin{aligned}
& R_{t}=a+b R_{t-1}+\varepsilon_{t} \\
& \varepsilon_{t} \mid I_{t-1} N\left(0, h_{t}\right) \\
& \log \left(h_{t}\right)=a+\sum_{j=1}^{q} \beta_{j}\left|\frac{u_{t-j}}{\sqrt{h_{t-j}}}\right|+\sum_{j=1}^{q} \lambda_{j}\left|\frac{u_{t-j}}{\sqrt{h_{t-j}}}\right|+\sum_{i=1}^{p} \delta_{i} h_{t-1}
\end{aligned}
$$

where, $\delta$ captures the asymmetric effect. The exponential nature of EGARCH makes sure that even of the parameter values are negative, that the conditional variance is always positive; thus, there is no need for parameter restrictions to impose non-negativity.

Bivariate EGARCH $(1 ; 1)$ model is used in this study to investigate the volatility spillover process. In spite of GARCH-type models being more popular in modelling the volatility process in financial series, EGARCH is used as the empirical studies have shown that the EGARCH model can more accurately describe the volatility dynamics (Bhar, 2001; Clinton and Michael, 2002). Thus, the present study examines the volatility spillover process using bivariate $\operatorname{EGARCH}(1,1)$ model.

$$
\begin{gathered}
\varepsilon t=\left(\begin{array}{c}
\varepsilon f, t \\
\varepsilon s, t
\end{array}\right) \wedge t-1 \sim N(0, \Omega), \quad \Omega t=\{\rho i j \sigma i, t \sigma j, t\} \\
\left|\frac{\varepsilon_{t-1}}{\sigma_{t-1}}-\sqrt{\frac{2}{\Pi}}\right|+t s+\frac{\varepsilon_{t-1}}{\sigma_{t-1}}+a \ln (\sigma 2 s, t)=\omega s+\psi s \\
\end{gathered}
$$




$$
\ln (\sigma 2 f, t)=\omega f+\psi f\left|\frac{\varepsilon_{t-1}}{\sigma_{t-1}}-\sqrt{\frac{2}{\Pi}}\right|+\frac{\varepsilon_{t-1}}{\sigma_{t-1}}+\alpha \mathrm{f} \ln \left(\sigma_{2, \mathrm{t}}^{2}-1\right)+\gamma \mathrm{fln}\left(\varepsilon_{2} f \mathrm{~s}, \mathrm{t}-1\right)
$$

The un-auto correlated residuals, $\varepsilon_{f, t}$ and $\varepsilon_{s, t}$ in equation (6) are obtained from the VECM model and $\Omega \mathrm{t}-1$ is the information set at $\mathrm{t}-1$. Equations (6) to (7) are then simultaneously estimated by maximizing the log-likelihood function:

$$
L(\theta)=-\sum_{t-1}^{T}\left(\ln \left[\Omega_{t}\right]+\varepsilon_{t}^{\prime} \Omega_{t}^{-1} \varepsilon_{t}\right)
$$

where $\Theta$ is the $13 X 1$ parameter vector of the model.

This two-step approach (the first step for the VECM and the second step for the bivariate EGARCH model) is asymptotically equivalent to a joint estimation of the VECM and EGARCH models (Greene, 1997). Estimating VECM and EGARCH model in one step is a complicated step and involves a large number of parameters. In addition, the residuals of Error Correction Term should be included in the conditional variance equation for estimating the volatility spillover. Otherwise the model will be misspecified, and the residuals obtained in VECM will be biased.

Results. As for the preliminary steps of the analysis, the study employed Augmented Dickey Fuller (1979) test for testing unit roots and its result are given in Table 1. According to the Augmented Dickey Fuller test results, the null hypothesis of non-stationary for spot and futures returns series of Gold are rejected at one per cent level, signifying that the return series of spot and futures markets are stationary.

Table 1. Augmented Dickey-Fuller Test Results

\begin{tabular}{|l|c|c|c|c|}
\hline \multirow{3}{*}{ Variables } & \multicolumn{4}{|c|}{ ADF Test Statistics } \\
\cline { 2 - 5 } & Intercept & Intercept \& Trend & Intercept & $\begin{array}{c}\text { Intercept \& } \\
\text { Trend }\end{array}$ \\
\cline { 2 - 5 } & \multicolumn{3}{|c|}{ Level } & \multicolumn{2}{c|}{ First Difference } \\
\hline Spot & -2.128924 & -0.943854 & $-37.89101^{*}$ & $-37.97604^{*}$ \\
\hline Futures & -2.117922 & -1.023131 & $-40.83142^{*}$ & $-40.90840^{*}$ \\
\hline
\end{tabular}

Note: ${ }^{*}$ - indicates significance at one percent level. Optimal lag length is determined by the Schwarz Information Criterion (SIC)

Source: survey data.

To assess the distributional properties of spot and futures return series, descriptive statistics are reported in the Table 2. There is evidence that market returns of futures and spot series are negatively skewed and also the kurtosis values of the market return series was much higher than 3 indicating that the spot and futures return distributions of Gold is fat-tailed or leptokurtic. Besides, the spot and futures return series is non-normal according to the Jarque-Bera test, which rejects normality at the $1 \%$ level. Moreover, the table reports the Q-statistics of Ljung-Box test for the standardized residuals and squared standardized residuals conducted up to 36 lags. The autocorrelation and ARCH effects is detected by the Q-statistics results in the time series as, in the case of both futures commodity market and gold spot market returns the standardized residuals and squared standardized residuals are auto correlated.

Furthermore, the null hypothesis of no ARCH effects is tested using the Engle (1982) ARCH-LM test statistics and its results are reported in the Table 2. There are significant ARCH effects on the spot and futures return data series of Gold commodity markets. This is confirmed, as the ARCH-LM test statistics are highly significant at one per cent level. 
Table 2. Descriptive Statistics of Return Series

\begin{tabular}{|l|c|c|}
\hline Statistics & Spot & Futures \\
\hline Mean & 0.000378 & 0.000381 \\
\hline Standard Deviation & 0.008925 & 0.010021 \\
\hline Skewness & -0.308646 & -0.412195 \\
\hline Kurtosis & 8.725375 & 11.89486 \\
\hline LB-Q(36) & $57.086^{*}$ & $77.761^{*}$ \\
\hline LB2-Q(36) & $473.79^{*}$ & $218.03^{*}$ \\
\hline JB & $1970.314^{*}$ & $4741.341^{*}$ \\
\hline ARCH-LM(1) & $7.529048^{*}$ & $131.4534^{*}$ \\
\hline
\end{tabular}

Notes: $L B(36)$ and LB2(36) are the Ljung-Box $Q$ statistics applied on returns and squared returns, respectively. JB is the Jarque-Bera statistic to test for normality. ARCH-LM(1) is a Lagrange multiplier test for ARCH effects for order one in the residuals (Engle, 1982). ${ }^{*}$ - denote the significance at the one percent level

Source: survey data.

Hence, as the Bivariate EGARCH model with generalized error distribution (GED) sufficiently records the volatility clustering and heteroscedastic effects, it is considered fit for modelling the spot and futures return volatility of the commodity markets. The estimates of Bivariate EGARCH model to find the volatility spillover mechanism which occurs between spot and futures commodity markets of Gold, is shown in Table 3.

Table 3. Empirical Results of Volatility Spillover for Gold Market

\begin{tabular}{|l|c|c|}
\hline Indicators & Spot Returns & Futures Returns \\
\hline \multirow{2}{*}{ Si } & $-0.532009^{*}$ & $-0.480722^{*}$ \\
& $(-5.799221)$ & $(-11.11558)$ \\
\hline \multirow{2}{*}{$\mathrm{Ii}_{\mathrm{i}}$} & $0.163603^{*}$ & $0.181833^{*}$ \\
$\mathrm{i}$ & $(10.29819)$ & $0.044679^{*}$ \\
& $0.038980^{*}$ & $(4.370023)$ \\
\hline \multirow{2}{*}{ ai } & $(3.924620)$ & $0.962007^{*}$ \\
& $0.956944^{*}$ & $(232.8891)$ \\
\hline \multirow{2}{*}{ Yi } & $(107.2008)$ & $-8.581615^{*}$ \\
\hline Residual Diagnostics & $-9.775197^{*}$ & $(-4.335924)$ \\
\hline Q2[36] & $(-9.632403)$ & $18.986(0.991)$ \\
\hline \multirow{2}{*}{ ARCH-LM[3] } & $28.157(0.822)$ & \multirow{2}{*}{$1.035678(0.375759)$} \\
\hline
\end{tabular}

Notes: Figures in parenthesis are z-statistics, ${ }^{*}$ - denote the significance at one level. Q2(36) represents the Ljung-Box Q-statistics for the model squared standardized residuals using 36 lags. ARCH-LM[3] is a Lagrange multiplier test for ARCH effects for order 3 in the residuals (Engle, 1982)

Source: survey data.

Table 3 presents the results of Bivariate EGARCH Model for Gold Market. The Bivariate EGARCH Model result reveals that the GARCH effects (measured by ai) are statistically significant; implying the degree of volatility persistence exists in the case of both Gold futures and spot market returns. This 
result indicates that there is a tendency for volatility to continue for long periods in both the markets, once a shock has occurred. The leverage effect parameters (Ti) are positive and statistically significant for both futures and spot market return, indicating existence of leverage effect. This indicates that positive shocks have greater impact on this market than the negative shocks. The table result reveals that the spillover coefficients (vi) are statistically significant for both futures and spot market return, indicating significant bidirectional spillovers exist across the futures and spot markets of Gold. This indicates that there is bi-directional flow of information between both the markets and both these markets are integrated with each other. It indicates that the investor can predict the behaviour of one market using the information from other market.

To check the robustness of Bivariate EGARCH $(1,1)$ model, the present study conducted the LjungBox (1978) test on the squared standardized residuals. Further, the ARCH-LM (Engle, 1982) test was employed to test the absence of any further ARCH effects. As can be seen in Table 3, the Ljung-Box Q2 statistics at 36 lags indicates lack of autocorrelation in the squared normalized residuals. Also, there is no serial dependence in squared residuals, as can be seen from the ARCH-LM tests. Hence, it can be seen from the results that Bivariate EGARCH model was reasonably well specified and can be considered as the most suitable model to document the ARCH (time-varying volatility) effects in the time series analysed.

Conclusions. The financial innovation management of volatility spillover process in the Gold Futures Market was examined in this Study. The study employs Exponential Generalized Autoregressive Conditional Heteroscedasticity (EGARCH) model to analyse the volatility spillover dynamics. The ARCHLM test statistics are highly significant at one per cent level, confirming that both the spot and futures returns data series of Gold markets have significant ARCH effects. The Bivariate EGARCH Model result reveals that the GARCH effects are statistically significant, signifying that in both Gold futures and spot market returns, volatility exists. The spillover coefficients are statistically significant for both futures and spot market return, indicating that there are significant bi-directional spillovers across the futures and spot markets of Gold. As there are significant volatility spillovers between the markets, it can be said that there is high level of integration between the markets. Here, all the available information is reflected in the current price as the market assimilates immediately new information and as a consequence there is no arbitrage opportunities. In contrast to the widely accepted hypothesis of the futures market, that due to its cost and hedging advantages, the futures market leads the spot market, the Indian Gold Futures market, during the period of study, fails to provide early information to spot market.

Author Contributions. For research articles with several authors, a short paragraph specifying their individual contributions must be provided. The following statements should be used conceptualization, review, methodology, and formal analysis, M. M.; Editing, visualization, supervision, S. M. M.

\section{References}

Bhar, R. (2001). Return and Volatility Dynamics in the Spot and Futures Markets in Australia: An Intervention Analysis in a Bivariate EGARCHX Framework. J. Fut. Mark., 21, 833-850. DOI:10.1002/fut.1903

Bhargava, V., Malhotra, D. K., Russel, P., \& Singh, R. (2012). An empirical examination of volatility spillover between the Indian and US swap markets. International Journal of Emerging Markets, 7 (3), 289-304.

Booth, G. G., Martikainen, T., \& Tse, Y. (1997). Price and volatility spillovers in Scandinavian stock markets. Journal of Banking \& Finance, 21, 811-823.

Chevallier, J., \& lelpo, F. (2013). Volatility spillovers in commodity markets. Applied Economics Letters, 20 (13), 1211-1227.

Ewing, B. T., \& Malik, F. (2013). Volatility transmission between gold and oil futures under structural breaks. International Review of Economics and Finance, 25, 113-121.

Feng, S. X., Lin, S. X., \& Ho, D. (2003). Spillover Effects in the Malaysian Palm Oil Futures and Cash Markets. Malaysian Journal of Economic Studies.

Greene W H. (1997). Econometric analysis (3rd edition). Engelwood Cliffs, NJ: Prentice Hall 
Hong, Y. (2001). A test for volatility spillover with application to exchange rates. Journal of Econometrics, 103, 183-224. Kaltalioglu, M., \& Soytas, U. (2011). Volatility Spillover from Oil to Food and Agricultural Raw Material Markets. Modern Economy, 2, 71-76.

Kanas, A. (1998). Volatility spillovers across equity markets: European evidence, Applied Financial Economics, 8(3), 245256, DOI: $10.1080 / 096031098333005$

Karmakar, M. (2009). "Price Discoveries and Volatility Spillovers in S\&P CNX Nifty Future Its Underlying Index CNX Nifty." Vikalpa 34 (2), 41-56.

Lahiani, A., \& Vo, T. (2013). Understanding Return And Volatility Spillovers Among Major Agricultural Commodities . The Journal of Applied Business Research, 29 (6), 1781-1790.

Lien, D., \& Yang, L. (2009). Intraday return and volatility spill-over across international copper futures markets. International Journal of Managerial Finance, 5 (1), 135-149.

Lin, S., \& Tamvakis, M. (2001). Spillover effects in energy futures markets. Energy Economics, 23, 43-56.

Mallika, M. \& Sulphey, M. M. (2018). Gold exchange traded fund - price discovery and performance. Scientific Annals of Economics and Business, 65(4), 477-495. http://DOI:10.2478/saeb-2018-0024

Mallikarjunappa, T., \& M, A. E. (2010). Price Discovery Process and Volatility Spillover in Spot and Futures Markets: Evidences of Individual Stocks. Vikalpa, 35 (2).

Mantu, K. M., Debashis, A., \& Babu, M. S. (2014). Price discovery and volatility spillovers in futures and spot commodity markets : Some Indian evidence . Journal of Advances in Management Research, 11 (2), 211-226.

Mattos, F., \& Garcia, P. (2006). Price Discovery and Risk Transfer in Thinly Traded Markets: Evidence from Brazilian Agricultural Futures Markets. Review of Futures Markets, 14, 471-483.

Mensi, W., Beljid, M., Boubaker, A., \& Managi, S. (2013). Correlations and volatility spillovers across commodity and stock markets: Linking energies, food, and gold. MPRA Paper No. 44395. University Library of Munich, German.

Mishra, A. K., Swain, N., \& Malhotra, D. K. (2007). Volatility Spillover between Stock and Foreign Exchange Markets: Indian Evidence. International Journal of Business, 12 (3), 343-359.

Nazlioglu, S., Erdem, C., \& Soytas, U. (2013). Volatility spillover between oil and agricultural commodity markets. Energy Economics, 36, 658-665

Pati, P. C., \& Rajib P. (2011). Intraday return dynamics and volatility spillovers between NSE S\&P CNX Nifty stock index and stock index futures, Applied Economics Letters, 18, 6, 567.

Sehgal, S., Rajput, N., \& Florent-Deisting. (2013). Price Discovery And Volatility Spillover:Evidence From Indian Commodity Markets. The International Journal of Business and Finance Research, 7 (3), 57-75.

Sehgal, S., Berlia, N. \& Ahmad, W. (2013). An Examination of Price Discovery and Volatility Spillovers of Crude Oil in Globally Linked Commodity Markets. International Journal of Economics \& Finance; 5 (5), 15-34

Shihabudheen, M. T., \& Padhi, P. (2010). Price Discovery and Volatility Spillover Effect in Indian Commodity Market . Indian Journal of Agricultural Economics, 65 (1), 101-117.

Srinivasan, P. (2012). Price Discovery and Volatility Spillovers in Indian Spot-Futures Commodity Market. The IUP Journal of Behavioral Finance, 9 (1), 70-85.

Srinivasan, P., \& Ibrahim, P. (2012). Price Discovery and Asymmetric Volatility Spillovers in Indian Spot-Futures Gold Markets. International Journal of Economic Sciences and Applied Research, 5 (3), 65-80.

Sy, M., Li, L., \& Nguyen, L. T. (2015). Volatility spillover from soybean oil futures to crude palm oil spot and futures: An empirical evidence. Proceedings of the 5th Conference on Derivative Markets 2015. Auckland, New Zealand.

Thenmozhi, M., \& Priya, S. (2008). Volatiity Spillover in Bullion and Energy Futures and Spot Market. Journal of Emerging Financial Markets, 1 (1), 85-108.

Thenmozhi, M., \& Thomas, S. M. (2007). Price discovery and volatility spillovers in spot and futures markets: evidence from India. Indian Journal of Capital Market, 4 (2), 1-28.

Trujillo-Barrera, A., Mallory, M., \& Garcia, P. (2012). Volatility Spillovers in U.S. Crude Oil, Ethanol, and Corn Futures Markets. Journal of Agricultural and Resource Economics, 37 (2), 247-262.

Tse, Y. (1999). The Journal of Futures Markets. Price Discovery And Volatility Spillovers In The Djia Index And Futures Markets, 19 (8), 911-930.

Wahab, M. \& Lashgari, M. (1993). Price Dynamics and Error Correction in Stock Index and Stock Index Futures Markets: A Cointegration Approach. Journal of Futures Markets. (13) 4, 711-742.

Wang, P., \& Wang, P. (2001). Equilibrium adjustment, basis risk and risk transmission in spot and forward foreign exchange markets. Applied Financial Economics, 11, 127-136.

Wiese, V. (1978). Use of commodity exchanges by local grain marketing organizations. In A. Peck (ed). Views from the trade (Chicago: Board of Trade of the City of Chicago, 1978).

Wong, K., \& Shum, W. (2010). Exchange-traded funds in bullish and bearish markets. Applied Economics Letters, 17 (16) 1615-1624.

Working, H. (1948). Theory of the inverse carrying charge in futures markets. Journal of Farm Economics, 30, 1-28.

Wu, F., Guan, Z., \& Myers, R. J. (2011). Volatility spillover effects and cross hedging in corn and crude oil futures. Journal of Futures Markets, 21 (1), 1052-1075. 
Xiaoqing, E. X., \& Fung, H. G. (2005). Cross market linkages between U.S. and Japanese precious metals futures trading. International Financial Markets, institutions and Money, 15, 107-124.

Yang, J., Yang, Z. \& Zhou, Y. (2012), Intraday price discovery and volatility transmission in stock index and stock index futures markets: Evidence from China. J. Fut. Mark., 32, 99-121. DOl:10.1002/fut.20514

Yang, J., Zhang, J., \& Leatham, D. J. (2003). Price and Volatility Transmission in international Wheat Futures Market. Annals of Economics and Finance, 4 (1), 37-50.

Zhong, M., Darratt, A. F. and Otero, R. 2004. Price discovery and volatility spillovers in index futures markets: some evidence from Mexico. Journal of Banking and Finance, 28, 3037-54.

Маліка Метью, Ph.D., Міжнародна школа менеджменту Джаганнатха (Індія);

M. М. Салфей, Ph.D., професор, Університет принца Саттама Бін Абдулазіза (Саудівська Аравія).

Інновації фінансового управління перетоком волатильності на індійському ринку золотих ф’ючерсів

Під перетоком волатильності розуміють волатильність фрінансових ринків, що може переходити від одного до іншого ринку. При иьому авторами наголошено, що однією із головних особливостей волатильності є ї̈ динамічність та рух. Традиційно процес волатильності залежить від обсягів нової інфоормації, що проникає на ринок. У статті проаналізовано особливості управління фрінансовими інноваціями, перетоку волатильності між індійським ринком ф'ючерсів та спот-ринком золотих товарів. Вихідні дані для дослідження сорормовано на основі результатів аналізу щоденних котирувань ф'ючерсів та спот-ринку товарно-сировинної біржі у Мумбаї протягом семи років (з 1 жовтня 2009 року до 30 вересня 2016 року). Для аналізу панельних даних використано модель двомірно-експоненційної узагальненої авторегресійної гетероскедастичності (EGARCH) з метою визначення інноваційних підходів до управління динамікою перетоку волатильності. На основі емпіричних результатів дослідження авторами доведено, що GARCH ефректи є статистично значущими, що свідчить про наявність волатильності як у випадку золотих ф'ючерсів, так і дохідності спот-ринку. Отримані результати підтверджують гіпотезу про існування тенденції волатильності протягом тривалого часу на обох ринках за умови появи нових шоків. Ефрект левериджу є позитивним та статистично значущим фрактором як для ринку ф'ючерсів, так і для дохідності спот-ринку. У зв'язку з цим авторами зазначено, що позитивні шоки мають більший вплив на аналізовані ринки, ніж негативні. Враховуючи отримані результати, авторами встановлено, що інвестор може використовувати інформацію одного ринку для прогнозування поведінки іншого. Авторами доведено, що ціни на ринках є чутливими до нової інформації. У статті зазначено, що на відміну від загальноприйнятої гіпотези про функціонування ф'ючерсного ринку, даний ринок $є$ лідером на спотовому ринку, завдяки економічним та страховим вигодам.

Ключові слова: модель EGARCH, золоті ф'ючерси, переток, дохідність, спот-ринок, волатильність.

Manuscript received: 18.02.2019.

(C) The author(s) 2019. This article is published with open access at Sumy State University. 